\title{
Determining Factors and Scenarios of Influence on Consumer Migration from the Regulated Market to the Deregulated Electricity Market
}

\author{
Heloísa P. Burin *[D, Julio S. M. Siluk, Graciele Rediske and Carmen B. Rosa (D)
}

check for updates

Citation: Burin, H.P.; Siluk, J.S.M.; Rediske, G.; Rosa, C.B. Determining Factors and Scenarios of Influence on Consumer Migration from the Regulated Market to the Deregulated Electricity Market. Energies 2021, 14, 65. https://dx.doi.org/10.3390/en14 010065

Received: 6 November 2020 Accepted: 21 December 2020 Published: 24 December 2020

Publisher's Note: MDPI stays neutral with regard to jurisdictional claims in published maps and institutional affiliations.

Copyright: () 2020 by the authors. Licensee MDPI, Basel, Switzerland. This article is an open access article distributed under the terms and conditions of the Creative Commons Attribution (CC BY) license (https: / / creativecommons.org/ licenses/by/4.0/).
Department of Production and Systems Engineering, Federal University of Santa Maria, 97105-900 Santa Maria, Brazil; jsiluk@ufsm.br (J.S.M.S.); graciele.rediske@ufsm.br (G.R.); carmen.b.rosa@ufsm.br (C.B.R.)

* Correspondence: heloisa.burin@acad.ufsm.br

\begin{abstract}
Due to the constant evolution of the electricity markets around the world, new possibilities for contracting electricity are emerging. In Brazil, there are two models available to the consumer: the regulated contracting environment and the free contracting environment. Because of these possibilities for contracting electricity, it is important that consumers know how to migrate from the regulated to the free environment when it is an advantage. This study was conducted following the premises of three techniques: systematic literature review, gray literature review, and expert panel. The following question was asked: What are the determining factors to be considered by the consumer at the moment decision to migrate from the regulated electricity market to the free market? In total, 7 factors were identified and discussed in the literature review. The experts who participated in the study pointed out 3 influential scenarios in this decision making to migrate. The main contribution of this study is to provide the consumer with subsidies for decision making, given the determining factors to be taken into account when deciding on migration or not. In addition, the study contributed to the sector through a comprehensive discussion about the scenarios faced by consumers and how they can influence decision making.
\end{abstract}

Keywords: decision making; determinant factors; energy contracting; electricity market; regulated market; deregulated market

\section{Introduction}

Energy consumption in the world continues to grow considerably [1,2], and electricity represents the highest rate of this growth [3]. Justified by the growth of the world population, development of urbanization, industrialization, and technologies [4]. Data from the U.S. Energy Information Administration estimates that by 2050 worldwide there will be an increase of approximately $49 \%$ in energy use, with Asia being the more expressive growth [5]. The authors [6] point out that China is responsible for $\frac{1}{4}$ of the world's electricity consumption.

Given this scenario, it is evident that there will be an increase in the industrial consumption of electricity for the production of goods and services, leading organizations to seek better conditions for contracting electricity. The pursuit of cost savings is quite representative of the industrial sectors since electricity is considered one of the most expensive products needed for production [7]. Many consumers end up managing their demands to reduce loads during peak hours-as the prices in these periods are relatively high, they achieve savings in their energy tariffs [8].

In search of this development, the world electricity market is modernizing and projects are being directed to better meet technological, economic, and political changes [9]. The electricity market is in the process of reconstruction [10], transforming the modern electrical industry into a restructured environment [11]. In many countries, electric power 
system transitions have already occurred or are underway [12], moving from a governmentcontrolled structure to a market-oriented context [13]. In this new environment, retailers buy energy from wholesale markets and resell it to final consumers through retail contracts [14]. This deregulation of the retail electricity market is an important trend in the energy sector worldwide. As the number of retail participants increases, competition in this market becomes more intense, directly influencing not only the prices charged for energy, but also the quality of services provided [15], improving the performance and efficiency of energy companies [11].

The total or partial opening of the electricity market introduces challenges to governments, energy producers, traders, retailers, and industries and society. Consumers must know how to identify the time to consider the migration from a regulated electricity market to a deregulated electricity market as an advantage. Sometimes, the necessity for adapting to the deregulated market and the lack of information can generate losses for consumers. In addition, it is not compensating for the effort and the relatively expensive initial investment. It is essential to know the functioning of these markets, aiming at choosing the best option for hiring [16].

In this sense, the present purpose article uses a combination of techniques, systematic literature review, gray literature review, and expert panel, to identify the determining factors in the process of migration from the regulated electricity market to the deregulated electricity market. Additionally, the scenarios that may influence the calculations which may generate risks and uncertainties affecting consumers' decision making were investigated. The research is contextualized in the Brazilian scenario, a country that has not yet consolidated itself in this migratory environment. In the national context, consumers demonstrate insecurity in this migration process. The study introduces, at times, regulations specific to Brazil, but they are adapted to other countries and relevant to the international context when addressing the migration of the consumer contract environment. So, through knowledge, study, and analysis of factors and scenarios, consumers have more information supporting this decision making. We know that through this research and the analysis of the factors and scenarios, it is possible to diagnose the aptitude to carry out a transition from one contracting environment to another, with a better business decision in the short, medium, and long term.

\section{Energy Markets}

Many countries have chosen to liberalize and decentralize all or part of their electricity markets. This decision allows consumers to compare offers and choose their suppliers according to their needs, services, and tariffs [17]. With this decentralization, energy generators compete in the market to cater to the expected demand of customers [18], this competition results in the attraction of innovative and more efficient participants [19]. Since deregulation in the mid-1990s in Europe, the number of electricity providers has increased substantially [20]. A deregulated market is capable of promoting energy production with lower prices and increasing the quality and quantity of services to be enjoyed by consumers [21]. The competition introduced will also result in greater network efficiency, with investments in transmission and distribution systems, in addition to more efficient plants [22].

The purchase of energy in deregulated markets relies on wholesale and retail environments. Electricity retailers are intermediaries between producers and consumers of electricity [14,23]. They are entities that buy energy in the wholesale electricity market and resell it to customers through retail contracts at a fixed price over some time, ranging from months to years $[11,14]$. For the closing of these contracts, retailers analyze the needs of consumers to estimate the load demand needed by each customer; this process guides the purchase of electricity, guaranteeing profits to retailers [23]. For there to be a competitive and efficient retail market, customers must seek and select the best contracts to their needs [24]; greater negotiation as well as supplier switching behavior would stimulate competitiveness and encourage a reduction in prices paid for electricity. The change of 
suppliers, allows the free choice of the energy mix to be contracted, ranging from totally ecological plans to common standards with a renewable energy ratio of $20 \%$ to $35 \%$ [20].

In the European market, since 1996, electricity systems have undergone significant changes [25]; the main objective of the reforms is the creation of a competitive and free choice domestic market for consumers, in addition to stimulating energy generation renewable sources and ensuring the security of supply [21]. Many countries opted for the liberalization of all or part of their markets, encouraging innovation, service flexibility, and prices offered to customers [17]. In New Zealand, electricity consumers are encouraged by the government to switch suppliers, always looking for the lowest prices on the market [26]. In Japan, after a reform plan, the implementation of competition in large-scale retail took place after the year 2016 [23]. In the United States, restructuring began in the 1990s, intending to improve service efficiency through competition [27]. In the state of California, at the beginning of deregulation when customers had the option to choose between their service provider or to remain with the concessionaire, very few chose to migrate to new suppliers [22]. In the United Kingdom, although liberalized more than ten years ago, small suppliers still face barriers to entering the so-called electricity retail market [28]. Italy started liberalizing the electricity market in 1999; under temporary regulation, the country's domestic consumers have two options, the choice of a supplier on the open market or a national electricity contract, which is regulated by the government, and the energy supplied by a distributor that acts as a local monopolist [29]. In China, there is a regulated market, where prices charged for electricity are regulated by the government [6], and the retail market, which is in the initial phase of liberalization [15].

In Brazil, the new model for the electricity sector was defined through Decree $\mathrm{N}^{\circ}$. 5163 , of 30 July 2004, and its premises were to guarantee the security of supply, the attraction of investments, financing, and low tariffs [30]. With that, the regulation for the commercialization of electric energy in the country, with two environments for the energy trade being established, the Regulated Contracting Environment (ACR) and the Free Contracting Environment (ACL). In the ACR environment, generation, distribution, and trading agents participate; energy purchase contracts are only made through auctions promoted by the Electric Energy Trading Chamber (CCEE) and regulated by the National Electric Energy Agency (ANEEL), where prices are fixed providing stability and guarantee of energy supply to consumers. In the ACL, generators, distributors, traders, and free and special consumers participate; the purchase and sale of electricity take place through freely negotiated bilateral contracts, following specific rules and procedures [31]. Table 1 shows data on electricity consumption and participation by the contracting environment in June 2019 and after one year, in June 2020.

Table 1. Consumption and participation of electric energy contracting environments in Brazil.

\begin{tabular}{c|cccccc}
\hline \multicolumn{3}{c}{ June/2019 } & \multicolumn{3}{c}{ June/2020 } \\
\hline & ACR & ACL & Total & ACR & ACL & Total \\
\hline Consumption (MW) & 41.789 & 19.230 & 61.019 & 40.326 & 18.391 & 58.717 \\
Participation & $71 \%$ & $29 \%$ & $100 \%$ & $69 \%$ & $31 \%$ & $100 \%$ \\
\hline Source: $[32]$
\end{tabular}
Source: [32].

The ACL environment has two types of consumers: free and special. The free consumer buys electricity for consumer units with a load equal to or greater than $2000 \mathrm{~kW}$, being served at any voltage, in addition to buying energy from any authorized concessionaire or permit holder of the National Interconnected System (SIN). The SIN is home to $96.6 \%$ of the country's total electricity production capacity, comprising plants, transmission lines, and distribution assets [33]. To serve the consumers with the lowest demand, there is a modality of special consumers, who can only buy energy from renewable sources and have contracted demand equal to or greater than $500 \mathrm{~kW}$ [34].

The specification of special consumers occurs to stimulate the generation and purchase of electricity from renewable sources. This occurs because of the sharp global growth in 
demand for electricity together with environmental concerns [35]. Increasing the share of energy generation from renewable sources is one of the main objectives of energy planning policies in many countries [36]. Such sources positively affect the energy markets, replacing expensive and polluting technologies [28]; besides, they promote a decline in the prices paid for electricity, enabling lower costs to consumers $[9,28,37]$.

The free market is already consolidated in the sale of Brazilian electric energy. In this market, the greater the supply of energy, the greater competition among participants, generating a tendency to reduce prices, making it more attractive to consumers. The benefits that this market offers instigates the migration to the ACL, but it is important that the consumer, before making the migration decision, is aware of both the conditions and the strategies of operation of this market. Because the ACL also offers risks and uncertainties to consumers, Table 2 shows a comparison between the two electric energy contracting environments available in Brazil.

Table 2. Comparison between electric energy contracting environments in Brazil.

\begin{tabular}{|c|c|c|}
\hline & ACL & ACR \\
\hline Consumer & Free and Special & Regulated \\
\hline Supplier & Supplier and trader & Local energy distributor \\
\hline Contract & $\begin{array}{l}\text { Bilateral, flexible, and freely negotiated } \\
\text { between agents }\end{array}$ & $\begin{array}{l}\text { Long term between supplier, and traders to } \\
\text { supply regulated consumers }\end{array}$ \\
\hline Source & $\begin{array}{l}\text { There is a possibility to choose the source to } \\
\text { be contracted }\end{array}$ & $\begin{array}{l}\text { There is no possibility to choose the } \\
\text { contracted source }\end{array}$ \\
\hline Prices & Agreements between buyer and seller & Prices established in auctions \\
\hline Recruitment & Freely traded & Through government-regulated auctions \\
\hline Predictability & $\begin{array}{l}\text { Contracts fix prices and make it possible to } \\
\text { forecast energy costs }\end{array}$ & $\begin{array}{l}\text { There is no predictability, prices vary from month } \\
\text { to month }\end{array}$ \\
\hline Risks & $\begin{array}{l}\text { Mistaken forecast of contracted demand, exposing } \\
\text { itself to PLD }\end{array}$ & $\begin{array}{c}\text { Consumer is protected by the local energy } \\
\text { distributor }\end{array}$ \\
\hline
\end{tabular}

The Brazilian government opted for the creation of the free market to expand energy offers, stimulate the reduction of prices to be paid, and consequently increase the competitiveness of industry and commerce [38]. When opting for the migration from the regulated to the free environment, companies seek mainly to predict the bill and reduce electricity costs [39], reaching up to 34\% [40]. Until December 2019, this market had 919 free consumers and 5951 special consumers, totaling 20,190 MW, which represents approximately $30 \%$ of all energy that is consumed in the country [40].

\section{Materials and Methods}

Methodologically, this research was organized in three stages, presented in Figure 1. The study was based on the qualitative exploratory approach, through a systematic literature review (SLR): covering factors mentioned as relevant by the academy; gray literature review: investigating all literature published by non-traditional publishers, such as the government or non-profit organizations involved in the process of migrating consumers from a regulated environment to a free market, when purchasing electricity; and experts panel: interviews with professionals in the electricity sector, in person, according to the interviewee's availability.

This research, under the guidance of these three techniques, aims to help researchers and consumers obtain a knowledge source from which they can consider before deciding to migrate from one market to another, which sometimes may not present itself as an advantageous process. Considering the objective of this research, research questions (RQ) were developed to synthesize the application of the techniques, so that they remain in the same proposed objective. Thus, the specific objective of the three applied steps remained to answer: What are the determining factors to be considered by the consumer when deciding to migrate from the regulated electricity market to the unregulated one? 


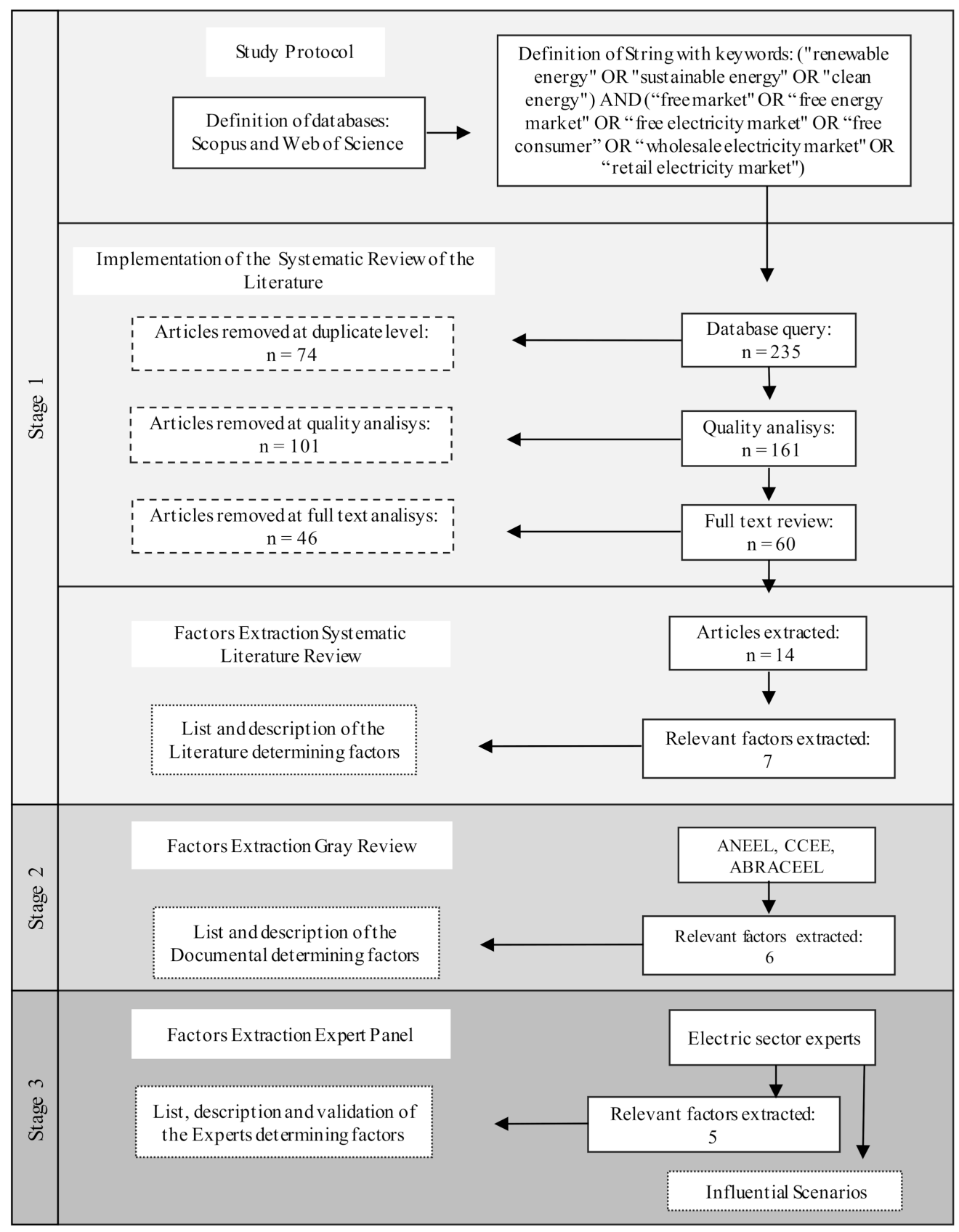

Figure 1. Research steps.

Step 1: The systematic literature review aims to identify one comprehensive selection of scientific journals that comprise the studied theme [41], using organized, transparent, and replicable producers at each step in the process [42]. The scope of this research is to detail the steps that influence the migration of the consumer currently owned by the ACR to the ACL. The value of driving an SLR comes from using it as a method that assists in the analysis of the existing completed and registered material produced by researchers, academics, and professionals [43]. In addition, the reviews are capable of balancing with rigor, relevance, and transparency the studies that are considered significant [44], enabling their use by professionals to make better-informed decisions, while contributing to the academic field [45]. An SLR is conventionally developed with the following characteristics: explicit study protocol, addressing pre-specified and highly focused research questions; study search methods; evaluation of studies to determine scientific quality; and explicit methods for combining the findings [44]. 
It was determined that the search protocol was part of the planning stage and consisted of outlining the fundamental steps for the realization of the SLR, explained in this section. For the selection phase, two scientific databases were chosen to search for academic publications: Scopus and Web of Science. Therefore, the combinations of the keywords ("renewable energy" OR "sustainable energy" OR "clean energy") AND ("free market" OR "free energy market" OR "free electricity market" OR "free consumer" OR "wholesale electricity market" OR "retail electricity market") were searched without period limitations. The databases search resulted in a total of 235 articles. This phase was carried out until January 2020. Next, we used the Mendeley reference manager to assist in the review process, remaining after the removal of duplicate 161 studies. Then, the articles were systematically reviewed, first analyzing the title, abstract, and keywords. This process resulted in 60 articles because the rest were not congruent with the study's theme. Afterward, the resulting articles were analyzed in their entirety, extracting only 14 studies that brought the authors some determining factor in the migration process from one market to another, from which 7 factors were extracted, which are shown in Table 3. The sequence of this study was carried out through a systematic methodology followed by a gray review and expert panel, to capture materials and information from different perspectives.

Table 3. Determinant factors for migration from Regulated Contracting Environment (ACR) to Free Contracting Environment (ACL) extracted from the systematic literature review and gray literature.

\begin{tabular}{|c|c|c|c|}
\hline PFV & Factor & Research Technique & Study Authors \\
\hline \multirow{4}{*}{ Internal Environment } & High energy demand during peak hours & Systematic literature review & {$[35,46-48]$} \\
\hline & Peak energy hours & Systematic literature review & {$[8,46,49]$} \\
\hline & $\begin{array}{l}\text { Adequacy to the billing measurement } \\
\text { system (SMF) }\end{array}$ & Gray literature & {$[39,50]$} \\
\hline & Customer Insight & Gray literature & [51] \\
\hline \multirow{3}{*}{ Financial } & Initial Investment & Systematic literature review & {$[48,52]$} \\
\hline & Contractual and financial customization & Gray literature & [51] \\
\hline & Rate change in ACR & Gray literature & {$[51,53]$} \\
\hline \multirow{3}{*}{ External Environment } & Risks with Contracts & Systematic literature review & {$[19,46,54-57]$} \\
\hline & $\begin{array}{l}\text { Variation of prices in the short term market } \\
\qquad(\mathrm{MCP})\end{array}$ & Systematic literature review & {$[46,49,54,56-58]$} \\
\hline & Credibility in the supplier and trader & Systematic literature review & {$[19,46]$} \\
\hline \multirow{3}{*}{ Regulations } & Migration procedures & Systematic literature review & [52] \\
\hline & Termination of the ACR energy contract & Gray literature & {$[39,51,59]$} \\
\hline & Return from ACL to ACR & Gray literature & {$[30,39,51,59]$} \\
\hline
\end{tabular}

Step 2: Gray literature, or literature published by non-traditional publishers, such as the government or non-profit organizations, can be particularly valuable for current awareness due to its nature [60]. This literature differs from the SLR in that they are materials produced by professionals who are not included in academic forums [61]. Common types of gray literature publications include reports (annual, research, technical, project, etc.), working papers, and government documents [62]. These publications do not go through peer review; emerging research can often be identified and communicated more quickly than if they had gone through the traditional publication process. In addition, the publication bias is usually reduced, since research in which an intervention shows to have a positive effect is usually valued above the negative results, distorting the results of the traditionally reported literature. The gray literature process is used to obtain research to support policies or practices [60]. On the other hand, such research can become risky, as often in gray literature, there is little factual scientific representation of data or analysis [63], researchers should be aware of, and investigate the veracity, and reliability of the information collected.

Because of the Brazilian energy market context, which has its characteristics, laws, and regulations, it is valid to identify factors fundamental to the consumer's migration from the 
regulated to the free market present in documents of government agencies, associations, and entities involved in the market power. A total of 6 factors were found that complement those found in the literature, assisting companies more objectively in deciding to migrate. In Table 3, it is possible to see the factors found as well as the related studies.

Following our screening, the entire evidence agency from the academic and gray literature was reviewed to identify findings of the factors that affect consumer decision making to migrate from one energy contracting environment to another. Then, to obtain a more complete and practical study, turned to reality, a panel with experts was structured. At this stage, the technical opinions of experts on the subject are extremely important.

Step 3: Expert panels are used when contributions and expert opinions are needed for an assessment [64]. Generally, a variety of experts are employed based on various fields of expertise to debate and discuss various courses of action and make recommendations. A variety of research questions can be addressed using expert panels to synthesize existing knowledge and issue recommendations [65]. The expert panel review process involves the following steps: (a) identifying the panel's experts, (b) setting the date of the panel's meeting and preparing supporting materials, (c) conducting the panel of experts, and (d) disseminate the results [66].

The development of this panel sought to involve experts in the Brazilian electricity sector, therefore considered by acting together companies with great influence in this market. These companies have been selected during the readings performed in steps 1 and 2 of this study. As a criterion for selection of experts, the choice of names with consolidated experience in the regulated electricity market and in a deregulated market was valued, occupying positions with influence, and expertise on the subject. The selected companies were public and private agencies related to the Brazilian government, and private companies, such as the local energy distributor.

The presentation of this panel sought to combine implementation strategies with evidence-based practices, and in real-world service environments. One panel member included a specialist representing the Ministry of Mines and Energy (MME), the agency responsible for formulating and ensuring the implementation of public policies for the sustainable management of energy and mineral resources, contributing to the country's socio-economic development. In addition, two specialists represented the Paulista Power and Light Company (CPFL) distributors, which aim to guarantee the supply of electricity to different classes of consumers: residential, industrial, commercial, rural, public sector, and others. Distribution companies have customers as consumers and, at the same time, are customers of the companies that generate and transmit energy.

The panel started with the factors derived from the systematic literature review and gray. The specialists were interviewed following a protocol, maintaining the objectivity of the research question. Each specialist analyzed the 13 factors, extracted in Steps 1 and 2, as well as their descriptions, and reported their opinion regarding their permanence for the study. Additionally, experts were invited to cite indispensable factors to be present in this decision to migrate consumers from the regulated to the unregulated environment, when they felt the need. As a result of this stage, the 13 factors presented were maintained and 5 new determining factors were added, shown in Table 4, with the final list being validated by the experts' panel.

Table 4. Factors pointed out by experts in the Brazilian electricity market.

\begin{tabular}{|c|c|c|}
\hline PFV & Factor & Specialist Company and Position \\
\hline Internal Environment & Load profile evaluation & $\begin{array}{c}\text { CCEE-specialist in energy models } \\
\text { and studies }\end{array}$ \\
\hline Financial & Expected return & $\begin{array}{l}\text { CCEE-specialist in energy models and } \\
\text { studies; CCEE-price analyst }\end{array}$ \\
\hline Financial & Risk aversion & CCEE-price analyst \\
\hline Regulations & ballast proof & CPFL-engineer \\
\hline External Environment & Supply risk & CPFL and engineer; CCEE-analyst \\
\hline
\end{tabular}


Given the constant changes from which the electricity market has been suffering all over the world, such as new opportunities, products, sources of generation, deregulation, and environmental challenges, at the end of the interviews, with the factors already validated, the specialists were questioned about scenarios that they considered to have an influence on the factors presented, which can generate uncertainties that impact consumer decision making. The question was as follows: Give your opinion on possible scenarios that may influence consumer's decision making regarding the migration from ACR to ACL. This risk analysis was considered by the present study due to the dynamism attributed to the energy market, whether in a regulated or free environment. There was a total return of 3 scenarios pointed out.

\section{Results and Discussions}

The determining factors in the migration of consumers from one energy contracting environment to another must be able to point out the consumer's performance concerning the migration process, therefore ensuring that the decision to leave the regulated market is made after analyzing this performance. In total, 18 determining factors were identified and classified into four points of fundamental views (PFV), they are (1) internal environment: consists of internal elements in an organization; (2) financial: deals with the financial movement of an organization; (3) external environment: it is the context where the organization exists, but with elements that operate outside its limits; and finally; (4) regulation: encompass the legal procedures to be adopted by consumers.

In Section 4.1, the factors obtained from RSL and gray literature are presented. Section 4.2 contains the factors collected through the expert panel of the Brazilian energy market, aiming at extracting information from people inserted in the work routine of commercialization and regulation of electricity. Finally, Section 4.3 presents the scenarios considered by the specialists for being able to influence the contracting of energy in a regulated and free environment.

\subsection{Factors Determining the Migration of Consumers from the Regulated to the Deregulated Electricity Market}

The 13 factors identified, extracted from the systematic literature review and gray literature, aim to objectively assist consumers in the regulated energy market in deciding to migrate to the free environment. In Table 3, it is possible to visualize these factors allocated in their respective PFV, the research technique used for collection, and the study from which it was extracted.

In Brazil, the regulated energy market has peak, intermediate, and off-peak hours. According to [53], peak hours are a daily period of 3 consecutive hours, except Saturdays, Sundays, and national holidays. The intermediate is from $1 \mathrm{~h}$ to $1 \mathrm{~h} 30 \mathrm{~min}$ before and after peak hours. In contrast, off-peak hours are the daily period with hours complementary to the others. Considering this factor, many companies in this contracting environment that have a high energy demand during peak hours, carry out the so-called energy exchange, managing their production so that the load used is the lowest possible during these times. With this, it is possible to obtain savings in energy bills, since at peak times the prices paid for consumption are higher [35,46-48]. Many consumers, however, although they perform this management, are unable to obtain significant gains, being viable and advantageous the migration to free contract environments, where the purchase of energy is made through contracts and the price paid for the amount does not vary, being possible the constant use of energy at peak times $[8,46,49]$.

Another factor to be taken into account is the consumer's adaptation to the Billing Measurement System (SMF); they must be regular with the system to start the purchase of energy in the free environment [39]. To be able to measure the energy flow used by consumers, it is necessary to install meters and potential and current transformers, which are the equipment that makes up the SMF [50]. After collecting the energy data, CCEE makes a comparison of the amounts recorded in the purchase and sale contracts with the generation 
and consumption values registered in the SMF, the difference between the verified energy and the contracted energy is accounted for and traded on the short term market (MCP).

With the increasing insertion of renewable sources for the generation of electric energy in the unregulated contracting environment, consumers choose to purchase energy from these sources not only by reducing costs in tariffs but also by the associated environmental appeal. The customer vision factor addresses the company's expectation concerning the opinion of its customers concerning the purchase of energy from renewable sources in the free market, enabling the disclosure of the business or an increase in sales [51]. In Brazil, $91 \%$ of customers value the company's reputation behind the brand when purchasing a product or service, globally, this number drops to $87 \%$ [67].

To migrate from ACR to ACL, an initial investment must be made. Large and small agents mention the high costs of having an adequate infrastructure for the deregulated energy market [52] such as the cost of installing efficient equipment to adapt to SMF [48]. In the study [16], the authors report on these initial investments, discussing the expenses with the energy to be contracted, the adequacy of the infrastructure, adherence to CCEE, and expenses with traders.

Since they are bilateral contracts freely negotiated between supplier and consumer, in the free environment, there is contractual and financial customization, with options for negotiating the payment methods for the amount of energy contracted. This payment flexibility brings benefits to consumers since payments can be made based on scheduled terms and available resources, which often vary according to the month, or the year [51]. Additionally, greater negotiation can result in lower prices to be paid for energy.

Both in the free and regulated environment, the contracts are for the amount of energy, if the producer does not comply with what is established, he will have to buy the energy difference in the MCP [54]. On the other hand, if the producer has a surplus of energy, he can sell it in the same market [68]. The settlement price for differences (PLD) is determined weekly and has a maximum and minimum price established to protect consumers, avoiding that in periods of peak load or power shortage prices are extremely high $[9,49]$. The variation in electricity prices over a year in long-term contracts and PLD was $0.3 \%$ and $8 \%$, respectively [69].

Energy tariffs are the way of ensuring that those responsible for the generation, transmission, distribution, and commercialization of energy in the country are adequately remunerated, covering operating costs and passing on quality service to the consumer in a regulated environment [53]. In Brazil, the tariff variation occurs according to the region and the service provider. Among concessionaires and permit holders, which are responsible for supplying energy to a given local, the average residential tariff is $0.557 \mathrm{R} \$ / \mathrm{kWh}$. The use of energy sources with low marginal production costs makes the prices paid for energy lower in the market $[9,13]$. On the other hand, the lack of security of supply due to risks of scarcity, by dependence on climatic conditions, causes volatility in the final prices of energy [70].

The risk factor with contracts is associated with the commitments that consumers must assume when signing an energy purchase contract, which can be long or short term [19]. In them, in addition to the duration, the volume to be delivered, the prices to be paid, and deadlines for the supply of all energy are freely negotiated $[46,54,55,57]$. Consumers must be able to predict how much energy they will consume, avoiding their exposure to the MCP, only well-planned contracts protect the customer from possible risks [39]. The authors [56] point out that the duration of contracts can reach 20 years.

In the so-called MCP, there is a wide variation in the prices to be paid for electricity. While the use of energy sources with low marginal production costs decreases the prices paid for energy in the market $[9,13]$, its lack of security of supply due to dependence on climatic conditions causes high volatility in final prices [70]. That is, when the system lacks operational reserve, the consumer tends to pay high prices for energy in the MCP [46,49,56-58]. The authors [54] point out that, while in the regulated environment the price paid for energy remains, in the free environment it varies according to the market. 
The credibility factor in the supplier and trader deals with how much consumers know or trust companies to deliver the contracted services $[19,46]$. Often these consumers have limited information, blindly opting for a retail company, these poorly qualified may not comply with contracts, supply low-quality energy [15], perform fraudulent charges, and provide terrible support to their client [24]. In the Brazilian market, traders are companies that buy energy from suppliers to resell consumers [39]. The suppliers are those who produce energy and compete in the market to meet the expected demands [18], the sale is made to traders or large consumers [70].

The migration procedures factor addresses the complexity that consumers encounter in the process of complying with the rules and deadlines for trading energy in a deregulated market [52]. In many cases, consumers do not have sufficient knowledge about the rules to migrate from a regulated to a free market, or, even poorly informed, do not meet the necessary deadlines properly. This bad administration can lead the consumer to run out of electricity, having to buy from local distributors or at MCP at a high price. The authors [15] stress the need for a perfect information disclosure system to improve market efficiency, making it more competitive and fair, making it easier for participants to understand the information released.

To start the migration from a regulated to a free environment, the consumer must analyze his current contract with the energy distribution concessionaire or permit holder, initiating the termination of his contract. In Brazil, these contracts usually have a term of 12 months and must be terminated at least 6 months in advance. For this termination, consumers must send a letter of denunciation to the distributor, accusing the termination of the contract, if there is a need to anticipate this process, there may be fines to be paid for this issue [39,51]. Normative resolution $\mathrm{N}^{\circ} 247 / 2006$ points out that, if the consumer is not successful or gives up the free contracting of energy, resulting in financial expenses for the concessionaire or permit holder, these will be the consumer's total responsibility [59]. It is important to highlight that the consumer, even in the free environment, remains linked to the distributor, as it is she who manages the local distribution network and enables the physical delivery of energy at the charge point.

In Brazil, Decree $N^{\circ}$ 5.163, 30 July 2004, addresses that as of 2005, distribution agents, vendors, self-producers, and free consumers must inform the MME by 1 August of each load forecast for the following five years [30]. Thus, if a consumer who is in the free market wants to return to the regulated market, he has a period of 5 years to notify the concessionaire responsible for the supply of energy in his region. It is up to the distributor to accept a shorter-term, depending on the amount of energy to be contracted. This factor implies to the consumer good planning and management of their contracts in the free environment so that there is no lack of energy avoiding exposure to MCP [39,51]. If the consumer gives upon returning to the regulated market, any financial repercussions for the concessionaire are the responsibility of the same [59]. Likewise, in the retail market, the retailer needs to analyze the needs and forecast the demand for cargo from customers to purchase electricity [23].

Both contracts executed in the regulated and the free market, involve many studies for the purchase of energy, delivery times, volumes, and prices to be paid, and the consumer must be aware of his option, knowing that his choice regarding the contracting environment must be the one that will bring you the greatest benefits and profitability. Eventual failures in both energy contracting environments can result in serious inconvenience for commercialization, distribution companies, and especially consumers.

\subsection{Factors Determining the Migration of Consumers from the Regulated to the Deregulated Environment from the Perspective of Specialists}

Due to the dynamism attributed to the energy contracting markets in Brazil, the panel with experts aimed at identifying determining factors in the migration of consumers from a regulated to a free market, based on the experience of people who live this process in practice. Thus, a total of 5 factors were identified, complementing those obtained in Steps 1 and 2 of the present study. Table 4 presents these factors together with the PFV to which 
they are associated and also presents the company in which the specialist works and the position he holds.

In the step of the panel with experts, a factor pointed out was the evaluation of the load profile, which proposes that consumers should know their consumption profile and the evolution of their demand, this can occur through the systematic monitoring of their load and by the certification of the efficient use of electric energy, with the use of certified equipment and with high performance. Besides, this factor is fundamental in countries with restrictions on migration to the free environment. In Brazil, the consumer must be within the minimum and maximum installed load range, stipulated by normative resolution $\mathrm{N}^{\circ}$ $247 / 2006$ [59]. In a retail market, the estimated load demand directly influences retailers' businesses, as it provides the basis for the decision making process of these companies [14].

From the financial point of view, two new factors were mentioned as fundamental by the specialists, they are expected return and risk aversion. The first, expected return, points to the need for the consumer to have defined the financial return he expects to obtain in the short, medium, or long term when he migrates from regulated to free contract. Such planning can avoid the impact of uncertainty on future prices to be paid for energy, providing better management of the organization's accounts and profits. The second, risk aversion, deals with consumer sentiment regarding the risk of an investment. The unregulated energy contracting environment can bring uncertainty to consumers, who should be well advised and confident of their decision to participate in this market, as poorly managed contracts can lead to grave losses for consumers.

The ballast proof factor refers to the fact that the consumer participating in the free market carries out proof of a financial ballast, which will guarantee that he will be able to pay for the contracted energy. This factor requires regulatory analysis, as it involves flexibilities or restrictions in its proof.

Pointed as a solution to the world dependence on fossil fuels for electricity generation, the implementation of renewable sources for this purpose occurs at an increasing rate in several countries $[46,48,71,72]$. Because they are sources that show variability and uncertainty, as they have intermittent energy generation and are subject to prolonged periods of resource scarcity, the Supply Risk factor addresses the risks in the supply of electricity from renewable energy sources. In periods of scarcity, the prices paid for electricity tend to increase $[57,58]$.

\subsection{Scenarios of Influence on Electricity Contracting}

To support consumer decision making, three scenarios were pointed out by experts during Step 3 of the present study. Thus, possible risks and uncertainties are analyzed in this section, so that consumers can know and position themselves in different energy contracting environments.

- Climate Risks

Climatic risks are directly associated with renewable energy generation systems. A transition to these sources is seen as a strategy to face climate crises $[73,74]$. These sources, such as wind and solar, are variable and have unique characteristics. When climatic conditions are favorable, the prices paid for energy in the electricity markets are low, however, these sources have an uncertain and intermittent nature, and it is often necessary to activate more expensive energy sources to compensate for the generation [70]. Therefore, while the use of these sources can decrease the prices paid for energy, they can increase the price volatility of the wholesale market [75], exposing the participants in these markets to high price risks.

Considerable increases in energy from renewable sources were highlighted in China's economic plans, which is the country with the highest energy production from these sources [76]. In Germany, water and wind sources are the main technologies that affect electricity prices [77]. In Brazil, for example, the electrical matrix is mainly composed of hydroelectric plants, with $69.7 \%$ representing them [78]. This source is subject to unpredictable water flows since the calculation is attributed to stored water, that is, in periods 
of scarcity the prices paid for energy tend to increase [57,58]. In systems with a lack of operational reserve, the values attributed to scarcity are offset in the cost of energy [46].

Therefore, it is assumed that the weather changes are unpredictable and can change the energy contracting scenario positively or negatively, having a strong influence on the electricity markets. This is a scenario to be considered by consumers who intend to migrate from one contracting environment to another, taking into account that in times of resource scarcity, the amount to be charged for energy in the free market can increase considerably, affecting those who do not have a solid long-term contract, having to acquire energy in the MCP exposing themselves to high acquisition prices. Or even, in cases where there are high levels of resources for energy generation, the supply tends to be greater than the demand, causing the prices paid to be lower. These variations in the price of energy due to supply and demand are more sensitive in the free market, and the market regulated by being more conservative remains on average without greater price fluctuations in the energy tariff paid by the consumer.

\section{- Growth of the Renewable Sources Sector}

A study by the International Energy Agency (EIA) estimates that between the years 2018 and 2050, global energy consumption by renewable sources tends to increase by $3.1 \%$ per year [5]. Worldwide growth is seen of proposals related to the reduction of environmental damages that involve the substitution of fossil energy sources and the increase of renewables [79]. These clean sources are expanding rapidly, reaching record levels of investments [80]. In China, the government is investing heavily in initiatives such as technical solutions, new laws, and comprehensive policies that involve environmental protection, and it has already been proven that these initiatives make a difference in environmental quality and human health [76]. The recent global pandemic (COVID-19), in turn, generated a crisis that affected all sectors, revealing a vulnerability in the current energy markets, and it is now a challenge to develop new economic and energy recovery plans, selecting and prioritizing efforts and investments for a renewable and sustainable future [74].

The wind energy presents studies and significant opportunities for growth in the coming years. Wind turbines are undergoing rapid technological developments to increase their competitiveness [81]. In Brazil, in August 2020, the National Electricity System Operator (ONS) recorded a record for instant wind generation, with a peak generation of 10,169 MW, enough to supply $97 \%$ of the electrical demand of the states that make up that northeast region of the country [82]. Together with wind power, the photovoltaic solar source will have significant growth in energy supply, with a projection from $4.9 \%$ in 2015 to $87 \%$ in 2050 [83]. Innovations, standards improvement, and rapid reduction in the cost of components, provide a democratization of solar energy [84]. Policies have allowed the emergence of business models, design and installation companies, increasing the production of inputs for this market [85]. Brazil, as a country with a vast territorial area and high solar irradiance, has the potential for the growth of this technology, increasing its representativeness in the national energy system $[79,86]$. These renewable sources positively affect the energy markets, replacing expensive and polluting technologies [28].

In Brazil, one perspective is the pricing of positive externalities, rewarding those who offer more energy with less environmental impact, such as what happens at RenovaBio. This is a National Biofuel Policy, instituted with the objectives of providing contributions to the commitments signed in the Paris Agreement; promoting the expansion of biofuels in the energy matrix, with an emphasis on regular fuel supply; and ensuring predictability for the market, inducing gains in energy efficiency and reduction of greenhouse gas emissions [87]. This model is based on market mechanisms, and without the use of taxes and subsidies, can be adapted to the electric energy sector, enabling competition between different technologies and sources, generating efficiency and promoting meritocracy.

Consumers should be aware of the growth in the generation of energy from renewable sources, following the studies and discussions that are being carried out around the world, mainly in more developed countries. When the consumers make the migration decision, it 
is necessary to know the possible changes in technologies that will affect the generation, distribution, and commercialization of energy. The increase in the sustainable appeal of agencies responsible for regulating the electricity sector encourages the usage of these sources and brings benefits to energy generation. This is a scenario that can favor the free energy market, as it is a contracting environment open to new strategies and seeks to foster competitiveness between generations to reduce commercialization prices. The introduction of these sources for energy generation influences the energy markets in the short, medium, and long term, an issue that is increasingly discussed by experts in the field.

- Political Risks and Regulatory Changes

The energy market scenario is always changing, facing a series of challenges, from political incentives that vary according to the region and sectors, new structures of rules and regulations, political and governance changes. The knowledge and analysis of these components are essential to understand the functioning of the energy markets.

The authors [79] argue in their study that Brazil is going through a challenging political moment, an instability that leads to concerns about the resumption of economic growth, causing a worsening of this scenario. They also state that investors as multinational manufacturers decide not to invest in the country due to the high risk attributed mainly to political and regulatory instability, consequently generating market uncertainties. As it is a country in which electricity is controlled by the State, the development and incentives for technologies are extremely dependent on government initiatives.

Ordinance $\mathrm{N}^{\circ}$ 514, 27 December 2018, which classifies the free consumer in Brazil as an agent of the commercialization category that purchases electricity in the free market for consumer units with a load equal to or greater than $2000 \mathrm{~kW}$ served at any voltage, it also stipulates that from January 1st of the years 2021, 2022, and 2023, the load will be equal to or greater than 1500,1000, and $500 \mathrm{~kW}$, respectively [34]. What constitutes a planned change in Brazilian regulations and consumers should be aware of and prepared for this possibility of buying energy.

The authors [21] point out in their study that if policymakers support regulatory and institutional changes, with limited interference from political forces, energy market reforms tend to generate benefits such as low and fair prices of electricity. The authors also argue that a dynamic, qualified, extensive, and persistent regulatory framework is necessary, capable of generating an adequately competitive energy market, increasing efficiency, and providing advantages to consumers. Local governments are important actors in monitoring and inspecting environmental policies, but they are dealing with the lack of incentives to prioritize these issues [88].

This scenario was pointed out by experts in the Brazilian energy market as being the most influential in consumers' decision making to migrate from a regulated to free energy contracting environment. Sudden changes in regulation can hamper both the development of the free market and foster competition and competitiveness in that market. The tendency is for more efforts to be invested so that there is a greater opening of the market, resulting in reformulations in the relevant legislation. Political support is also of paramount importance for this decision making, promoting greater incentives for contracting energy in the free market, given that a political crisis can affect the investment of companies in a given country and the breaking of agreements with important equipment suppliers that can develop the electrical system.

\section{Conclusions}

Electricity contract markets are topics of debate and studies around the world. In Brazil, there are two contracting environments, regulated and free, the first being controlled by the government and the second with bilateral contracts freely negotiated between generating agents, traders, and consumers. Both markets have advantages, but also risks and uncertainties, which almost always end up positively or negatively affecting the prices paid for electricity by consumers. Therefore, consumers must know how to identify the advantageous moment to carry out the migration from one energy contraction environment 
to another. That said, this study presented a combination of methods to identify, from the perspective of the internal environment, external environment, financial and regulation, the determining factors to be considered because of the possibility of carrying out-migration. In addition to this result, through the panel with experts, it was possible to identify scenarios that may influence consumer decision making, as well as to trace trends for the electricity sector and the assertive positioning of medium and high voltage consumers.

The combination of the three research techniques proposed in the methodology brought reliability and realistic character to the study. With the review, it was possible to identify that the migration of consumers from the regulated market to the deregulated electricity market is a topic of interest to the academic scientific community. It was also observed that, due to very specific rules and regulations, each country is in an energy commercialization stage, with some markets being fully liberalized and others in the process. In the gray review, where documents from Brazilian government agencies, associations, and entities involved in the energy market were analyzed, it was found that although Brazil has two energy contracting environments, with rules and limitations for migrating to the free market, there are proposals for this market to be fully liberalized, giving consumers more options and promoting competitiveness among agents operating in this segment. In the factor validation phase, the panel with experts was essential for the research to have a practical basis, addressing the opinion of people who experience the energy commercialization routine. The invited experts were receptive to the questions, contributing to the improvement of this study. Besides, it was possible to observe an engagement so that this issue generates more results, research, and knowledge for consumers because, according to them, consumers are the ones who stimulate competitiveness by making this system work.

This research contributes to researchers, consumers, and all agents involved in the electricity sector, providing an in-depth analysis of the migration of consumers from a regulated to the liberalized environment. It can be seen that the decision to migrate to a deregulated market is tempting since the economic benefits that this market can provide are high. However, the free environment is characterized by being a more unstable market than the regulated one, thus becoming a decision that entails possible risks that need to be carefully analyzed by the consumer before making a decision. This study provides the consumer with a broad discussion on the eighteen determining factors to be taken into account when deciding to migrate to the free market, describing the importance that each factor has in this decision making process. In addition to the factors, three risk scenarios with a greater possibility of interference in these markets are discussed, addressing each one of them, and consumers may have the foundation and support to work under different uncertainties.

Author Contributions: Conceptualization, H.P.B., J.S.M.S., G.R. and C.B.R.; Funding acquisition, J.S.M.S.; Investigation, H.P.B. and C.B.R.; Methodology, H.P.B. and G.R.; Resources, H.P.B. and G.R.; Supervision, J.S.M.S. and C.B.R.; Visualization, J.S.M.S. and C.B.R.; Writing-original draft, H.P.B., G.R. and C.B.R. All authors have read and agreed to the published version of the manuscript.

Funding: This research was funded by the National Institute of Science and Technology in Distributed Generation (INCTGD), and the financing agencies (CNPq process 465640/2014-1, CAPES process No. 23038.000776/2017-54 and FAPERGS 17/2551-0000517-1). Siluk was supported by a research grant of CNPq-Brasil (CNPq process Siluk No. 311926/2017-7).

Acknowledgments: The authors thank INCTGD, CAPES, CNPq, and FAPERGS for the financial support received for the development of this work.

Conflicts of Interest: The authors declare no conflict of interest. 


$\begin{array}{ll}\text { Abbreviations } & \\ \text { Abbreviations } & \text { Explanation } \\ \text { ACL } & \text { Free Contracting Environment } \\ \text { ACR } & \text { Regulated Contracting Environment } \\ \text { CCEE } & \text { Electric Energy Trading Chamber } \\ \text { ANEEL } & \text { National Electric Energy Agency } \\ \text { SIN } & \text { National Interconnected System } \\ \text { SLR } & \text { Systematic Literature Review } \\ \text { MME } & \text { Ministry of Mines and Energy } \\ \text { CPFL } & \text { Paulista Power and Light Company } \\ \text { PFV } & \text { Points of Fundamental Views } \\ \text { SMF } & \text { Billing Measurement System } \\ \text { MCP } & \text { Short Term Market } \\ \text { PLD } & \text { Settlement Price for Differences } \\ \text { ONS } & \text { National Electricity System Operator }\end{array}$

\section{References}

1. Koo, C.; Hong, T.; Park, J. Development of the life-cycle economic and environmental assessment model for establishing the optimal implementation strategy of the rooftop photovoltaic system. Technol. Econ. Dev. Econ. 2018, 24, 27-47. [CrossRef]

2. Putti, K.; Toth, Z. Economic analysis of the Hinkley Point $C$ nuclear power plant based on the available data. In Proceedings of the 6th International Youth Conference On Energy, IYCE, Budapest, Hungary, 21-24 June 2017.

3. Helgesen, P.I.; Tomasgard, A. An equilibrium market power model for power markets and tradable green certificates, including Kirchhoff's Laws and Nash-Cournot competition. Energy Econ. 2018, 70, 270-288. [CrossRef]

4. Ari, E.S.; Gencer, C. Proposal of a novel mixed integer linear programming model for site selection of a wind power plant based on power maximization with use of mixed type wind turbines. Energy Environ. 2020, 31, 825-841. [CrossRef]

5. EIA. Today in Energy. Available online: https://www.eia.gov/todayinenergy / detail.php?id=41433 (accessed on 13 August 2020).

6. Wu, W.; Lin, B. Application value of energy storage in power grid: A special case of China electricity market. Energy 2018, 165, 1191-1199. [CrossRef]

7. Teberge, C.R.; Sodré, E. Estudo de Viabilidade: Mercado Livre vs Mercado Cativo. Rev. Eng. e Pesqui. Apl. 2019, 4, 81-89. [CrossRef]

8. Panikovskaya, T.; Chechushkov, D. Consumer behavior on the Russian electricity market. In Proceedings of the 55th International Scientific Conference on Power and Electrical Engineering of Riga Technical University, Riga, Latvia, 12-13 October 2014; pp. 227-231.

9. Ahlstrom, M.; Ela, E.; Riesz, J.; O’Sullivan, J.; Hobbs, B.F.; O’Malley, M.; Milligan, M.; Sotkiewicz, P.; Caldwell, J. The Evolution of the Market: Designing a Market for High Levels of Variable Generation. IEEE Power Energy Mag. 2015, 13, 60-66. [CrossRef]

10. Li, G.; Shi, J. Agent-based simulation on WGenCo bidding in day-ahead electricity markets. In Proceedings of the 61st Annual IIE Conference and Expo Proceedings, Reno, NV, USA, 21-25 May 2011.

11. Chawda, S.; Bhakar, R.; Mathuria, P. Uncertainty and risk management in electricity market: Challenges and opportunities. In Proceedings of the 2016 National Power Systems Conference (NPSC), Bhubaneswar, India, 19-21 December 2016; pp. 1-6.

12. Nakano, R.; Miwa, T.; Morikawa, T. Comparative analysis on citizen's subjective responses related to their willingness to pay for renewable energy in Japan using latent variables. Sustainability 2018, 10, 2423. [CrossRef]

13. Gallego-Castillo, C.; Victoria, M. Cost-free feed-in tariffs for renewable energy deployment in Spain. Renew. Energy 2015, 81, 411-420. [CrossRef]

14. Yang, J.; Zhao, J.; Luo, F.; Wen, F.; Dong, Z.Y. Decision-Making for Electricity Retailers: A Brief Survey. IEEE Trans. Smart Grid 2018, 9, 4140-4153. [CrossRef]

15. Jin, L.; Chen, C.; Wang, X.; Yu, J.; Long, H. Research on information disclosure strategies of electricity retailers under new electricity reform in China. Sci. Total Environ. 2020, 710, 136382. [CrossRef]

16. Machado, V.d.C.; Barassuol, R.M. Viabilidade econômico-financeira da migração do mercado cativo para o mercado livre de energia: Um estudo de caso da universidade de Cruz Alta. In Proceedings of the Seminário Internacional sobre Desenvolvimento Regional, Santa Cruz do Sul, Rio Grande do Sul, Brasil, 11-13 September 2019; p. 23.

17. Do Prado, J.C.; Qiao, W.; Qu, L.; Agüero, J.R. The next-generation retail electricity market in the context of distributed energy resources: Vision and integrating framework t. Energies 2019, 12, 491. [CrossRef]

18. Hanna, R.; Disfani, V.R.; Kleissl, J. A game-theoretical approach to variable renewable generator bidding in wholesale electricity markets. In Proceedings of the 48th North American Power Symposium, NAPS-2016, Denver, CO, USA, 18-20 September 2016.

19. Ndebele, T.; Marsh, D.; Scarpa, R. Consumer switching in retail electricity markets: Is price all that matters? Energy Econ. 2019, 83, 88-103. [CrossRef]

20. Neumann, R.; Mehlkop, G. Framing electricity plan choices to enhance green energy usage: A choice experiment with panel data from Germany. Energy Res. Soc. Sci. 2020, 70, 101741. [CrossRef] 
21. Kaller, A.; Bielen, S.; Marneffe, W. The impact of regulatory quality and corruption on residential electricity prices in the context of electricity market reforms. Energy Policy 2018, 123, 514-524. [CrossRef]

22. Razeghi, G.; Shaffer, B.; Samuelsen, S. Impact of electricity deregulation in the state of California. Energy Policy 2017, 103, 105-115. [CrossRef]

23. Gao, Y.; Zhou, X.; Ren, J.; Zhao, Z.; Xue, F. Electricity purchase optimization decision based on data mining and Bayesian game. Energies 2018, 11, 1063. [CrossRef]

24. Mulder, M.; Willems, B. The Dutch retail electricity market. Energy Policy 2019, 127, 228-239. [CrossRef]

25. Pezzutto, S.; Grilli, G.; Zambotti, S.; Dunjic, S. Forecasting Electricity Market Price for End Users in EU28 until $2020-M a i n$ Factors of Influence. Energies 2018, 11, 1460. [CrossRef]

26. Ndebele, T. Assessing the potential for consumer-driven renewable energy development in deregulated electricity markets dominated by renewables. Energy Policy 2020, 136, 111057. [CrossRef]

27. Dahlke, S. Effects of wholesale electricity markets on wind generation in the midwestern United States. Energy Policy 2018, 122, 358-368. [CrossRef]

28. Fu, H.; Zhang, X.-P. Market Equilibrium in Active Distribution System with $\mu$ VPPs: A Coevolutionary Approach. IEEE Access 2017, 5, 8194-8204. [CrossRef]

29. Fontana, M.; Iori, M.; Nava, C.R. Switching behavior in the Italian electricity retail market: Logistic and mixed effect Bayesian estimations of consumer choice. Energy Policy 2019, 129, 339-351. [CrossRef]

30. ANEEL. Decreto No 5.163, de 30 de julho de 2004. Available online: http://biblioteca.aneel.gov.br/index.html (accessed on 12 January 2020).

31. CCEE. Ambiente livre e ambiente regulado: Contratação de energia. Available online: https://www.ccee.org.br/portal/faces/ pages_publico/como-participar/ambiente-livre-ambiente-regulado?_afrLoop=432799226429957\&_adf.ctrl-state=js6o0tv0d_1\# !\%40\%40\%3F_afrLoop\%3D432799226429957\%26_adf.ctrl-state\%3Djs6o0tv0d_5 (accessed on 10 April 2020).

32. CCEE. Informações ao mercado mensal: Contabilização junho de 2020. Available online: https://www.ccee.org.br/portal/ faces / pages_publico / o-que-fazemos /infomercado?_afrLoop=432998264672552\&_adf.ctrl-state=js6o0tv0d_14\#! $\% 40 \% 40 \% 3 F \_$ afrLoop\%3D432998264672552\%26_adf.ctrl-state\%3Djs6o0tv0d_18 (accessed on 15 May 2020).

33. ANEEL. Energia no Brasil e no Mundo. Available online: http:/ /www2.aneel.gov.br/ (accessed on 17 August 2020 ).

34. ANEEL. Portaria No 514, de 27 de dezembro de 2018. Available online: http:/ / biblioteca.aneel.gov.br/index.html (accessed on 15 January 2020).

35. Liu, M.; Quilumba, F.; Lee, W. A Collaborative Design of Aggregated Residential Appliances and Renewable Energy for Demand Response Participation. IEEE Trans. Ind. Appl. 2015, 51, 3561-3569. [CrossRef]

36. Pillot, B.; Al-Kurdi, N.; Gervet, C.; Linguet, L. An integrated GIS and robust optimization framework for solar PV plant planning scenarios at utility scale. Appl. Energy 2020, 260, 114257. [CrossRef]

37. Panos, E.; Densing, M. The future developments of the electricity prices in view of the implementation of the Paris Agreements: Will the current trends prevail, or a reversal is ahead? Energy Econ. 2019, 84, 104476. [CrossRef]

38. CCEE. 20 anos do mercado brasileiro de energia elétrica. Available online: https://www.ccee.org.br/relatoriodeadministracao/ (accessed on 5 May 2020).

39. ABRACEEL. Cartilha Mercado Livre de Energia Elétrica. Available online: https://abraceel.com.br/biblioteca/2019/05/cartilhamercado-livre-de-energia-eletrica/ (accessed on 26 April 2020).

40. ABRACEEL. Boletim Abraceel da Energia Livre. Available online: https://abraceel.com.br/topico/biblioteca/boletim/ (accessed on 2 May 2020).

41. Dresch, A.; Lacerda, D.P.; Antunes Júnior, J.A.V. Design Science Research: A Method for Science and Technology Advancement; Springer: New York, NY, USA, 2014.

42. Littell, J.; Corcoran, J.; Pillai, V. Systematic Reviews and Meta-Analysis; Oxford University Press: New York, NY, USA, 2008.

43. Fink, A. Conducting Research Literature Reviews: From the Internet to Paper, 2nd ed.; Sage Publications: London, UK, 2005.

44. Dixon-Woods, M.; Bonas, S.; Booth, A.; Jones, D.R.; Miller, T.; Sutton, A.J.; Shaw, R.L.; Smith, J.A.; Young, B. How can systematic reviews incorporate qualitative research? A critical perspective. Qual. Res. 2006, 6, 27-44. [CrossRef]

45. Latapí Agudelo, M.A.; Johannsdottir, L.; Davidsdottir, B. Drivers that motivate energy companies to be responsible. A systematic literature review of Corporate Social Responsibility in the energy sector. J. Clean. Prod. 2020, 247, 119094. [CrossRef]

46. Ela, E.; Billimoria, F.; Ragsdale, K.; Moorty, S.; Osullivan, J.; Gramlich, R.; Rothleder, M.; Rew, B.; Supponen, M.; Sotkiewicz, P. Future electricity markets: Designing for massive amounts of zero-variable-cost renewable resources. IEEE Power Energy Mag. 2019, 17, 58-66. [CrossRef]

47. Roldán Fernández, J.M.; Burgos Payán, M.; Riquelme Santos, J.M.; Trigo García, Á.L. Renewable generation versus demand-side management. A comparison for the Spanish market. Energy Policy 2016, 96, 458-470. [CrossRef]

48. Talwariya, A.; Singh, P.; Kolhe, M. A stepwise power tariff model with game theory based on Monte-Carlo simulation and its applications for household, agricultural, commercial and industrial consumers. Int. J. Electr. Power Energy Syst. 2019, 111, 14-24. [CrossRef]

49. Pinter, T.; Vokony, I. Regulatory influence analysis on EOM (energy only market) in consideration of electric power generation mix. In Proceedings of the 6th International Youth Conference on Energy, IYCE, Budapest, Hungary, 21-24 June 2017; pp. 1-7. 
50. CCEE. O que fazemos: Medição, Medirores e Sazonalização. Available online: https://www.ccee.org.br/portal/faces/ oquefazemos_menu_lateral/medicao?_adf.ctrl-state=14wef3wfn5_1\&_afrLoop=152024028762476\#!\%40\%40\%3F_afrLoop\%3D1 52024028762476\%26_adf.ctrl-state\%3D14wef3wfn5_5 (accessed on 4 February 2020).

51. CCEE. Capacita CCEE: Portal de Aprendizado. Available online: https://ccee.micropower.com.br/Performa/Web/Lms/ Student/CatalogView.aspx (accessed on 16 February 2020).

52. Freire, L.M.; Neves, E.M.A.; Tsunechiro, L.I.; Capetta, D. Perspectives of Smart Grid in the Brazilian Electricity Market. In Proceedings of the 2011 IEEE PES Conference on Innovative Smart Grid Technologies Latin America (SGT LA), Medellin, Colombia, 19-21 October 2011.

53. ANEEL. Gestão de Recursos Tarifários. Available online: https:/ /www.aneel.gov.br/gestao-de-recursos-tarifarios (accessed on 24 March 2020).

54. Aquila, G.; Rocha, L.C.S.; Rotela Junior, P.; Pamplona, E.D.O.; Queiroz, A.R.D.; Paiva, A.P.D. Wind power generation: An impact analysis of incentive strategies for cleaner energy provision in Brazil. J. Clean. Prod. 2016, 137, 1100-1108. [CrossRef]

55. Block, C.; Collins, J.; Ketter, W. Agent-based competitive simulation: Exploring future retail energy markets. In Proceedings of the 12th International Conference on Electronic Commerce: Roadmap for the Future of Electronic Business, Honolulu, HI, USA, 2-4 August 2010; pp. 68-77.

56. Jin, T.; Shi, T.; Park, T. The quest for carbon-neutral industrial operations: Renewable power purchase versus distributed generation. Int. J. Prod. Res. 2018, 56, 5723-5735. [CrossRef]

57. Neto, D.P.; Domingues, E.G.; Calixto, W.P.; Alves, A.J. Methodology of Investment Risk Analysis for Wind Power Plants in the Brazilian Free Market. Electr. POWER COMPONENTS Syst. 2018, 46, 316-330. [CrossRef]

58. Philpott, A.; Read, G.; Batstone, S.; Miller, A. The New Zealand Electricity Market: Challenges of a Renewable Energy System. IEEE Power Energy Mag. 2019, 17, 43-52. [CrossRef]

59. ANEEL. Resolução Normativa No 247, de 21 de dezembro de 2006. Available online: http:// biblioteca.aneel.gov.br/index.html (accessed on 16 January 2020).

60. Jewell, S.T. 6-Providing meaningful information: Part D-Current awareness. In A Practical Guide for Informationists; DeRosa, A.P., Ed.; Chandos Publishing: Newark, NJ, USA, 2018; pp. 63-70. ISBN 978-0-08-102017-3.

61. Garousi, V.; Felderer, M.; Mäntylä, M.V. Guidelines for including grey literature and conducting multivocal literature reviews in software engineering. Inf. Softw. Technol. 2019, 106, 101-121. [CrossRef]

62. Soldani, J.; Tamburri, D.A.; Van Den Heuvel, W.-J. The pains and gains of microservices: A Systematic grey literature review. J. Syst. Softw. 2018, 146, 215-232. [CrossRef]

63. Farace, D.; Schöpfel, J. Grey Literature in Library and Information Studiesnull; Walter de Gruyter: Berlin, Germany, 2010; ISBN 9783598441493.

64. Kraines, M.A.; Uebelacker, L.A.; Gaudiano, B.A.; Jones, R.N.; Beard, C.; Loucks, E.B.; Brewer, J.A. An adapted Delphi approach: The use of an expert panel to operationally define non-judgment of internal experiences as it relates to mindfulness. Complement. Ther. Med. 2020, 51, 102444. [CrossRef]

65. Waltz, T.J.; Powell, B.J.; Matthieu, M.M.; Chinman, M.J.; Smith, J.L.; Proctor, E.K.; Damschroder, L.J.; Kirchner, J.E. Innovative methods for using expert panels in identifying implementation strategies and obtaining recommendations for their use. Implement. Sci. 2015, 10, A44. [CrossRef]

66. Washington, S.P.; Lord, D.; Persaud, B.N. Use of Expert Panels in Highway Safety: A Critique. Transp. Res. Rec. 2009, 2102, 101-107. [CrossRef]

67. Portal da Comunicação. Uma Causa para Chamar de Sua. Available online: http://portaldacomunicacao.com.br/2019/03/umacausa-para-chamar-e-sua/ (accessed on 18 February 2020).

68. Ramos, D.S.; Guarnier, E.; Witzler, L.T. Using the seasonal diversity between renewable energy sources to mitigate the effects of Wind generation uncertainties. In Proceedings of the 6th IEEE/PES Transmission and Distribution: Latin America Conference and Exposition, Montevideo, Uruguay, 3-5 September 2012.

69. ABRACEEL. Boletim Anual da Energia Livre-2019. Available online: https://abraceel.com.br/destaques/2020/02/boletimanual-do-mercado-livre-2019/ (accessed on 5 March 2020).

70. Pinho, J.; Resende, J.; Soares, I. Capacity Investment on electricity markets undr supply and demand uncertainty. Energy 2018, 150, 1006-1017. [CrossRef]

71. Cunha, J.; Ferreira, P. A risk analysis of small-hydro power (SHP) plants investments. Int. J. Sustain. Energy Plan. Manag. 2014, 2, 47-62. [CrossRef]

72. Sorknæs, P.; Djørup, S.R.; Lund, H.; Thellufsen, J.Z. Quantifying the influence of wind power and photovoltaic on future electricity market prices. Energy Convers. Manag. 2019, 180, 312-324. [CrossRef]

73. Burke, M.J.; Stephens, J.C. Political power and renewable energy futures: A critical review. Energy Res. Soc. Sci. 2018, 35, 78-93. [CrossRef]

74. Vanegas Cantarero, M.M. Of renewable energy, energy democracy, and sustainable development: A roadmap to accelerate the energy transition in developing countries. Energy Res. Soc. Sci. 2020, 70, 101716. [CrossRef]

75. Peng, D.; Poudineh, R. Electricity market design under increasing renewable energy penetration: Misalignments observed in the European Union. Util. Policy 2019, 61, 100970. [CrossRef]

76. Tilt, B. China's air pollution crisis: Science and policy perspectives. Environ. Sci. Policy 2019, 92, 275-280. [CrossRef] 
77. Moreno, B.; Díaz, G. The impact of virtual power plant technology composition on wholesale electricity prices: A comparative study of some European Union electricity markets. Renew. Sustain. Energy Rev. 2019, 99, 100-108. [CrossRef]

78. CCEE. Informações ao mercado mensal: Contabilização dezembro de 2019. Available online: https://www.ccee.org.br/portal/ faces/pages_publico/o-que-fazemos/infomercado?showFlag=F\&_afrLoop=17701423003935 (accessed on 16 April 2020).

79. dos Santos Carstens, D.D.; da Cunha, S.K. Challenges and opportunities for the growth of solar photovoltaic energy in Brazil. Energy Policy 2019, 396-404. [CrossRef]

80. Genc, T.S.; Reynolds, S.S. Who should own a renewable technology? Ownership theory and an application. Int. J. Ind. Organ. 2019, 63, 213-238. [CrossRef]

81. Watson, S.; Moro, A.; Reis, V.; Baniotopoulos, C.; Barth, S.; Bartoli, G.; Bauer, F.; Boelman, E.; Bosse, D.; Cherubini, A.; et al. Future emerging technologies in the wind power sector: A European perspective. Renew. Sustain. Energy Rev. 2019, 113, 109270. [CrossRef]

82. ONS. Histórico da Operação. Available online: http:/ / www.ons.org.br/paginas/resultados-da-operacao/historico-da-operacao (accessed on 21 September 2020).

83. Breyer, C.; Bogdanov, D.; Aghahosseini, A.; Gulagi, A.; Child, M.; Oyewo, A.S.; Farfan, J.; Sadovskaia, K.; Vainikka, P. Solar photovoltaics demand for the global energy transition in the power sector. Prog. Photovoltaics Res. Appl. 2018, 26, 505-523. [CrossRef]

84. Choudhary, P.; Srivastava, R.K. Sustainability perspectives-A review for solar photovoltaic trends and growth opportunities. J. Clean. Prod. 2019, 227, 589-612. [CrossRef]

85. Rigo, P.D.; Siluk, J.C.M.; Lacerda, D.P.; Rediske, G.; Rosa, C.B. A model for measuring the success of distributed small-scale photovoltaic systems projects. Sol. Energy 2020, 205, 241-253. [CrossRef]

86. Rediske, G.; Siluk, J.C.M.; Michels, L.; Rigo, P.D.; Rosa, C.B.; Cugler, G. Multi-criteria decision-making model for assessment of large photovoltaic farms in Brazil. Energy 2020, 197, 117167. [CrossRef]

87. ANP. RenovaBio. Available online: http://www.anp.gov.br/producao-de-biocombustiveis/renovabio (accessed on 10 October 2020).

88. Zheng, L.; Na, M. A pollution paradox? The political economy of environmental inspection and air pollution in China. Energy Res. Soc. Sci. 2020, 70, 101773. [CrossRef] 